\title{
Analysis of the Failure of PLC Master Station Communication and DCS DELTA V ON MOV (Motor Operated Valve) at PT. TRANS-Pasific Petrochemical Indotama
}

\author{
Arik Syaiful Rasid ${ }^{\mathrm{a}, 1, *}$, Affan Bachri ${ }^{\mathrm{b}, 2}$, Rahman Arifuddin ${ }^{\mathrm{b}, 3}$ \\ ${ }^{\text {a1 }}$ Department of Electrical Engineering Faculty Engineering Universitity of Islam Lamongan, J1. Veteran 53A Lamongan, \\ Lamongan and 62214, Indonesia \\ b2 Department of Electrical Engineering Faculty Engineering Universitity of Islam Lamongan, J1. Veteran 53A Lamongan, \\ Lamongan and 62214, Indonesia \\ b3 Department of Electrical Engineering Faculty Engineering Universitity of Merdeka Malang, Jl. Taman Agung, \\ Karangbesuki, Kec. Sukun, Malang and 65146, Indonesia \\ ${ }^{1}$ ariksyaifu182@gmail.com*; ${ }^{2}$ asrasid@tppi.co.id ; ${ }^{3}$ rahman.arifuddin@unmer.ac.id
}

\section{ABSTRACT}

Keywords

Motor Operated Valve (MOV)

Distributed Control

System (DCS)

Programmable

Logic Controller (PLC)

\begin{abstract}
The development of technology nowadays is very rapid in various fields especially in industrialization that can support a reliable production process, one of which is a motor operated valve (MOV) which is expected to operate continuously. At PT TPPI, there are 37 motor operated valve that are installed using Modbus communication, which currently has a problem with communication namely blinking (opening and closing for a moment) which sits on the condensate trip pump so the refinery stops which can cause billions of rupiah in losses. With these losses, various tests are carried out so that they can find the cause of the MOV blinking that can increase the depth of the system. Checking or retrieving data based on Ohm's legal theory, conductors, insulators, induction electric motors, motors ( Motor Operated valve), PLC, DCS and Modbus. Based on this theory. It can determine the resistance, isolator and conductor of the RS485 cable whether it is still good or not, besides that it can also know the ability of MOV, PLC, DCS whether it can still send signals using software modbus. This testing uses a Fluke brand multi meter with type 875 to measure the resistance that the resistance value obtained is greater than the calculation results, for testing isulation resistance using the Kyoritsu brand megger with the 3007A model the value is very good. To check DCS using Dell delta V server type 690 precision, it is found that serial communication cannot be redundant, whereas for checking PLC master station using Dell inspiration 1464 laptop with modscan 32 software, the results obtained PLC A can output signals and PLC B signal intermittent. This research or this analysis can find out MOV blinking caused by cable resistance, PLC master station B and Modbus serial.
\end{abstract}

\section{Introduction}

The technology development nowadays is very rapid in various fields especially in industrialization that can support a reliable production process, one of which is a motor operated valve (MOV) which is expected to operate continuously. At PT TPPI there are 37 motor operated valve that are installed using modbus communication, which currently has a problem with communication[1] namely blinking (opening and closing for a moment) which sits on the condensate trip pump so that the refinery stop which cost billions of rupiahs[2].

This has happened since commissioning in 2005 and occurs every two weeks and in 2008 a system interlock modification on the DCS side by adding a timer for 2 seconds so that the condensate trip pump, the refinery shutdown and caused billions of rupiah losses.

In addition, the communication problem is compounded when the MOV is damaged and there are no obsolete parts, with this background the author chooses the title "FAILURE OF PLC MASTER STATION COMMUNICATION AND DCS DELTA V ON MOV (MOTOR OPERATED VALVE) AT PT. TRANS-PASIFIC PETROCHEMICAL INDOTAMA". This MOV communication system uses RS 485 cable in series between the MOV to the other MOV by using the master station as an interface to the DCS via serial communication.[3]

111 I $\mathrm{P}$ a g e 


\section{Method}

The method used in research is a case study whose model focuses on the exploration of "bounded system" for one particular case or in some cases in detail with in-depth data mining. Various sources of information that are rich in context are carried out for data mining[4][5][6].

Research participants were selected using a purposive technique with the help of key people. Through purposive technique, researchers select research participants and research sites with the aim to study or to understand the main problems to be studied. Research participants and research locations selected by this technique are adjusted to the research objectives. The data collection method uses interview, observation and document methods for the following details:

1. Literature Study Phase.

This literature study was taken from several data such as data sheets and reference books that used as a basis for processing data, this stage has been carried out at PT. TPPI since 2013 including:

a. Study of conductors

b. Study of insulators

c. Study of the motor operated valve MX-05 operating system

d. Study of PLC master station operating systems

e. Study of distributed control system ( Delta V Emerson )

2. Interview Phase

At this stage, we held a discussion or meeting with KS Wong from the flow serve from Singapore in the General Manager Building at PT.TPPI on November 23, 2016, at the meeting discussing the failure of PLC master station communication and DCS delta V on the MOV[7].

3. The cable checking phase

This stage is to ensure the RS 485 communication cable from the MOV to the master station that is used still has a good value for use by means of a resistant test measurement, this stage is carried out in the Offsite Area of PT. TPPI on 02-10 February 2020. For this stage, using the following formula:

$$
R=\frac{L}{A}
$$

Information:

$1=$ Channel Length (meter)

rho $=$ Resistence Type of Cable for Copper 1,68 $\times 10^{8}$

$A=$ Wire Cross Sectional are $\left(\mathrm{mm}^{2}\right)$

This formula is the ability of a material to withstand an electric current

4. PLC master station checking Phase

This stage ensures that the PLC sends signals to the MOV on an ongoing basis at the 900A offsite PT.TPPI area on 02-03 February 2020.

5. Checking the distributed control system delta $\mathrm{V}$ phase

This phase is to ensure the serial communication module uses is still good which is done in the 900A offsite area of PT. TPPI are on 05 February 2020.

6. System testing and analysis phase

Test the system that has been integrated as a whole to ensure that the system runs as normal as it did on 11 February 2020. 


\section{Results and Discussion}

\subsection{Test Continuty Result}

Table 1. Continuty Result

\begin{tabular}{|c|c|c|c|c|c|c|}
\hline \multirow[b]{2}{*}{ No. } & \multirow[b]{2}{*}{ Tag No } & \multicolumn{2}{|c|}{ Continuty Test } & \multirow{2}{*}{$\begin{array}{l}\text { Date } \\
\text { Check }\end{array}$} & \multirow{2}{*}{$\begin{array}{l}\text { Cable Length } \\
\text { (m) }\end{array}$} & \multirow{2}{*}{ Information } \\
\hline & & Open & Close & & & \\
\hline 1 & 990-HV-9021 & OL & 51,4 & $02 / 02 / 2020$ & 1.050 & $\begin{array}{l}\text { PLC Master Station } \\
\text { A ke HV } 9021\end{array}$ \\
\hline 2 & 990-HV-9013 & OL & 1,8 & $02 / 02 / 2020$ & 20 & 9021 to 9013 \\
\hline 3 & 990-HV-9402 & OL & 0,9 & $02 / 02 / 2020$ & 20 & 9013 to 9402 \\
\hline 4 & 990-HV-9405 & OL & 1,9 & $02 / 02 / 2020$ & 20 & 9402 to 9405 \\
\hline 5 & 990-HV-9016 & OL & 2,4 & $02 / 02 / 2020$ & 20 & 9505 to 9016 \\
\hline 6 & 990-HV-9017 & OL & 1,2 & $03 / 02 / 2020$ & 20 & 9016 to 9017 \\
\hline 7 & 990-HV-9014 & OL & 1,1 & $03 / 02 / 2020$ & 20 & 9017 to 9014 \\
\hline 8 & 990-HV-9015 & OL & 1,2 & $03 / 02 / 2020$ & 20 & 9014 to 9015 \\
\hline 9 & 920-HV-2002 & OL & 51,6 & $03 / 02 / 2020$ & 905 & 9015 to 2002 \\
\hline 10 & 990-HV-9009 & OL & 55,6 & $06 / 02 / 2020$ & 1050 & $1005 \mathrm{~A}$ to 9009 \\
\hline 11 & $920-H V-2000$ & OL & 50,1 & $07 / 02 / 2020$ & 905 & 9020 to 2000 \\
\hline
\end{tabular}

Based on table 1, the cable resistance value can be known or calculated theoretically by fomula 1 and the results in table 2 .

Table 2. Continuty Result

\begin{tabular}{|c|c|c|c|c|c|c|}
\hline \multirow[t]{2}{*}{ No. } & \multirow[t]{2}{*}{ TagNo } & \multirow{2}{*}{$\begin{array}{c}\text { Cable Length } \\
\text { (m) }\end{array}$} & \multicolumn{2}{|c|}{$\begin{array}{c}\text { Contonuty Test } \\
(\mathrm{Ohm})\end{array}$} & \multirow{2}{*}{$\begin{array}{l}\text { Calculation } \\
\text { with } E q \\
\text { (Ohm) }\end{array}$} & \multirow[t]{2}{*}{ Status } \\
\hline & & & Open & Close & & \\
\hline 1 & 990-HV-9021 & 1.050 & $\mathrm{OL}$ & 51,4 & & $\mathrm{tGo}$ \\
\hline 2 & 990-HV-9013 & 20 & $\mathrm{OL}$ & 1,8 & & Good \\
\hline 3 & 990-HV-9402 & 20 & $\mathrm{OL}$ & 0,9 & & Good \\
\hline 4 & 990-HV-9405 & 20 & $\mathrm{OL}$ & 1,9 & & Good \\
\hline 5 & 990-HV-9016 & 20 & OL & 2,4 & & Good \\
\hline 6 & 990-HV-9017 & 20 & $\mathrm{OL}$ & 1,2 & & Good \\
\hline 7 & 990-HV-9014 & 20 & $\mathrm{OL}$ & 1,1 & & Good \\
\hline 8 & 990-HV-9015 & 20 & OL & 1,2 & & Good \\
\hline 9 & $920-H V-2002$ & 905 & $\mathrm{OL}$ & 51,6 & & ot Goos \\
\hline 10 & 990-HV-9009 & 1050 & $\mathrm{OL}$ & 55,6 & & Go \\
\hline 11 & 920-HV-2000 & 905 & $\mathrm{OL}$ & 50,1 & & ot Goor \\
\hline
\end{tabular}

From the results of these calculations, the value of 40,32 is the maximum value allowed on each MOV cable network, the results of which can be seen in table 2.

\subsection{Distributed Control System Delta V Check Results}

The card distributed control system is assessed for card 37 and 38 that work redundant but the system does not work normally because seria card 38 always fail.

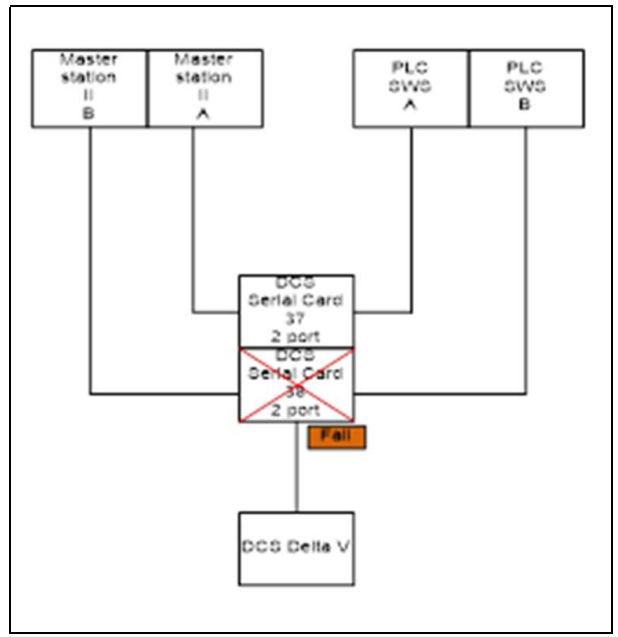

Fig. 1. Communication Series 
Table 3. Data Serial Card

\begin{tabular}{|c|c|c|c|c|c|}
\hline Card & Port & Panel & Status & $D S C$ & Keterangan \\
\hline \multirow{2}{*}{37} & 1 & SWS A & ON & $\mathrm{ON}$ & \\
\hline & 2 & MOV A & ON & $\mathrm{ON}$ & \\
\hline \multirow{2}{*}{38} & 1 & SWS B & OFF & FAIL & Serial status card in DSC fail \\
\hline & 2 & MOV B & OFF & FAIL & Serial status card in DSC fail \\
\hline \multirow{2}{*}{37} & 1 & SWS A & OFF & BLANK & \\
\hline & 2 & MOV A & ON & $\mathrm{ON}$ & \\
\hline \multirow{2}{*}{38} & 1 & SWS B & OFF & FAIL & Serial status card in DSC fail \\
\hline & 2 & MOV B & OFF & FAIL & Serial status card in DSC fail \\
\hline \multirow{2}{*}{37} & 1 & SWS A & OFF & BLANK & \\
\hline & 2 & MOV A & OFF & BALNK & \multirow{6}{*}{$\begin{array}{l}\text { DSC will not be on until the card is removed } \\
\text { and re-installed } \\
\text { After being removed and installed again, the } \\
\text { DSC status will turn on } \\
\text { After the } 38 \text { card is removed and installed } \\
\text { again, the serial card status in the DSC } \\
\text { changes to fail }\end{array}$} \\
\hline \multirow{2}{*}{38} & 1 & SWS B & $\mathrm{ON}$ & FAIL & \\
\hline & 2 & MOV B & OFF & FAIL & \\
\hline \multirow{2}{*}{38} & 1 & SWS B & ON & $\mathrm{ON}$ & \\
\hline & 2 & MOV B & ON & ON & \\
\hline 37 & 1 & SWS A & OFF & FAIL & \\
\hline
\end{tabular}

From checking the results obtained in table 3, serial card 38 always fails and the system will not run.

\subsection{PLC Master Station Check Results}

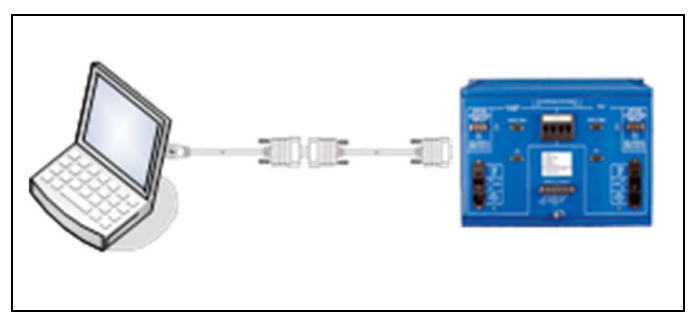

Fig. 2. PLC Master Station Test

1. PLC Master Station A

a. To ensure PLC A is already communicating with a Laptop so we ping the ip address with the following results :

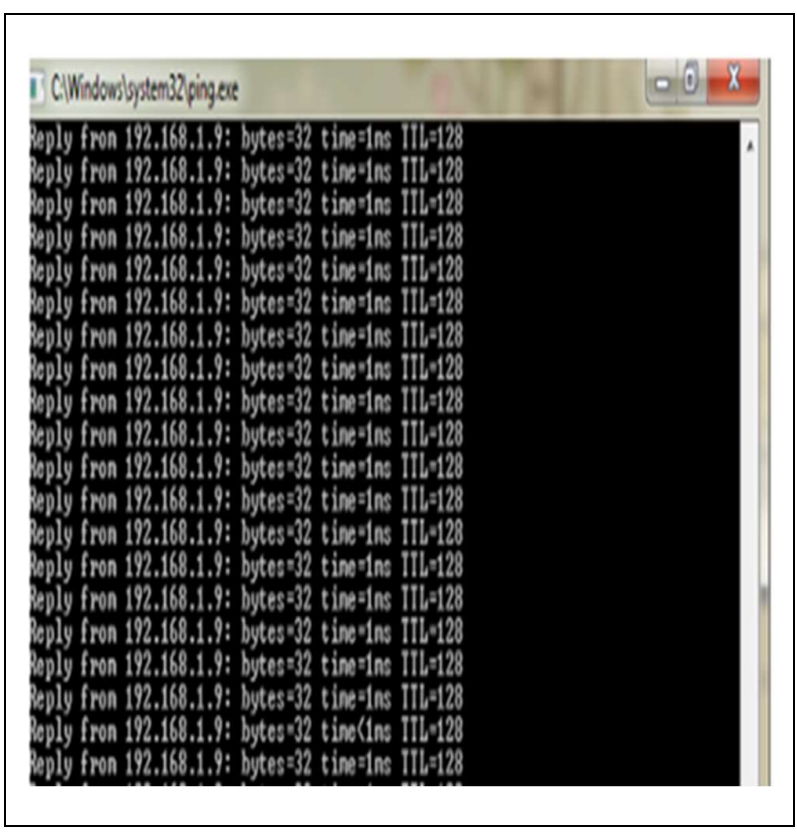


Fig. 3. Ping IP Address PLC A Result

b. To ensure PLC Master Station A is sending data, testing is done using modscan32 with the results as figure 4

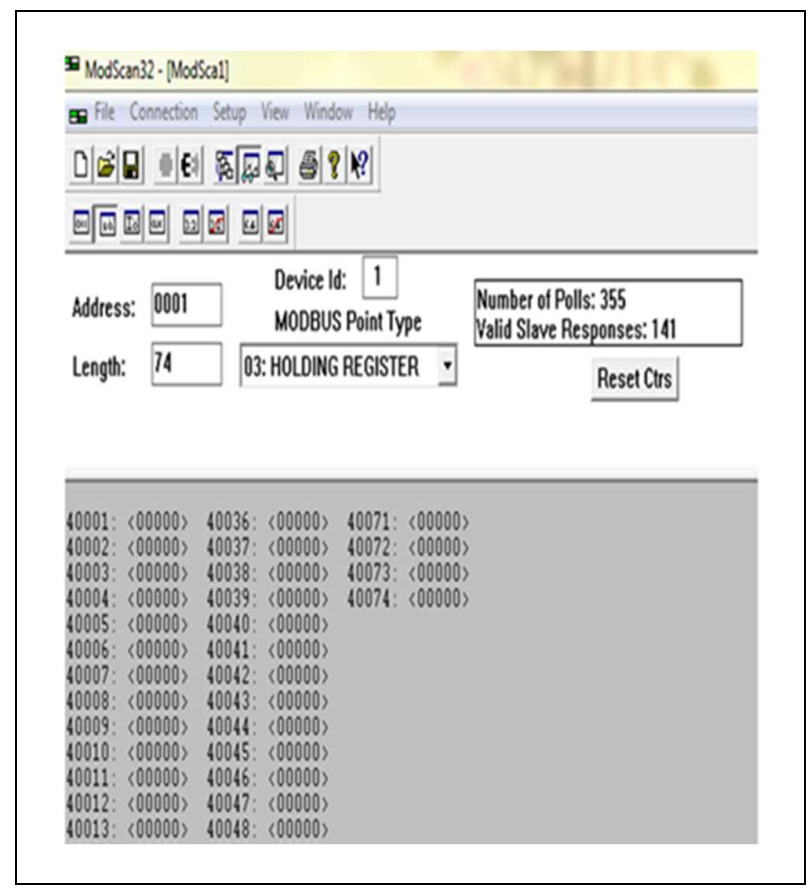

Fig. 4. Modscan32 Result

Checking result of PLC master station A the result is that the PLC sends to the laptop continuously and is seen in Figure 3 and Figure 4

1. PLC Master Station B

a. To ensure PLC A is communicating with the Laptop then we do ping ip address with the following results, figure 5

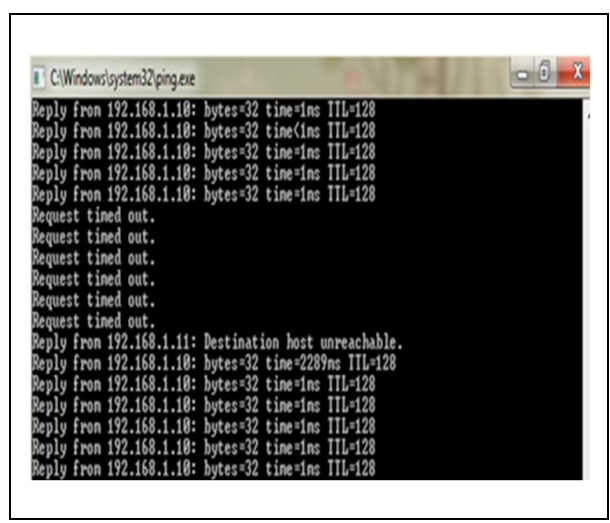

Fig. 5. Ping IP Address PLC B First Result

b. To ensure the PLC Master Station B sends data it is tested using modscan32 with the results as below.figure 6 and figure 7 


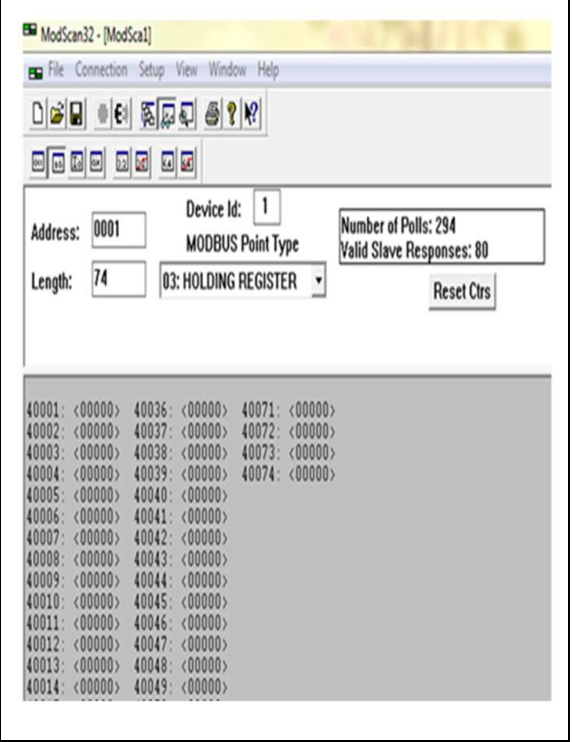

Fig. 6. Modscan32 PLC B First Result

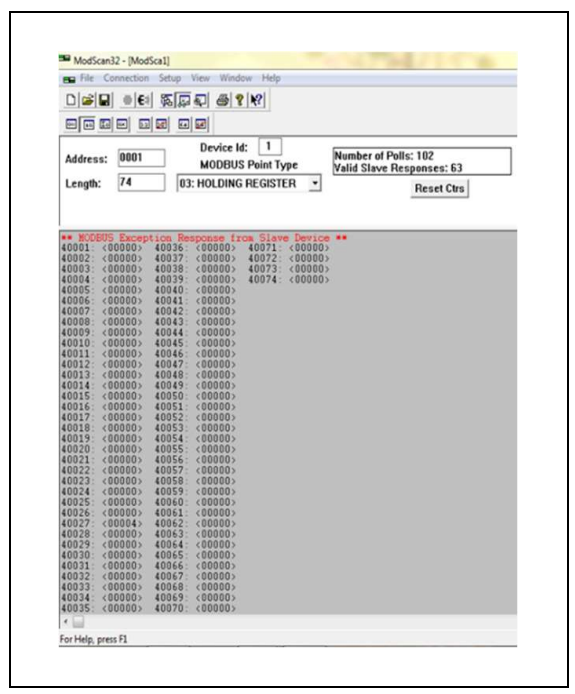

Fig. 7. Modscan32 PLC Second Result

The result of checking the PLC master station B shows that the PLC can send a signal but when the intermittent time is seen pin Figure 5 with a code request time out which means there is no reply from the recipient of the message and basically the packet sent has reached the recipient, but PLC does not replu.

Meanwhile the result of checking on the modscan on figure 6 where initially the PLC sends data continuously and in Figure 7 the PLC cannot send data, so that when PLC B becomes the master it cannot send data continuously.

\section{Conclusion}

a. The results of measuring cable resistance are greater than the calculated value. This resistance value greatly affects the amount of current flowing in the cable. The higher the resistance, the smaller the current so that it has the potential to occur in MOV blinking, details can be seen in table 2 . 
JEEMECS (Journal of Electrical Engineering, Mechatronic and Computer Science) ISSN 2614-4859

Vol. 3, No. 2, August 2020, pp. 111-118

doi https://doi.org/10.26905/jeemecs.v3i2.4163

b. PLC master station A can send signals in accordance with the working principle, but PLC Master station B msends signals intermitten so that it has the potential for blinking in the MOV.

c. In this research the calculation is only focused on the resistance and cable insulation, for further research can be developed using impedance.

d. On the result of the analysis in Chapter $\mathrm{V}$, the suggestion that must be done is to modify the Modbus RTU system to direct DCS or hardwire as shown below

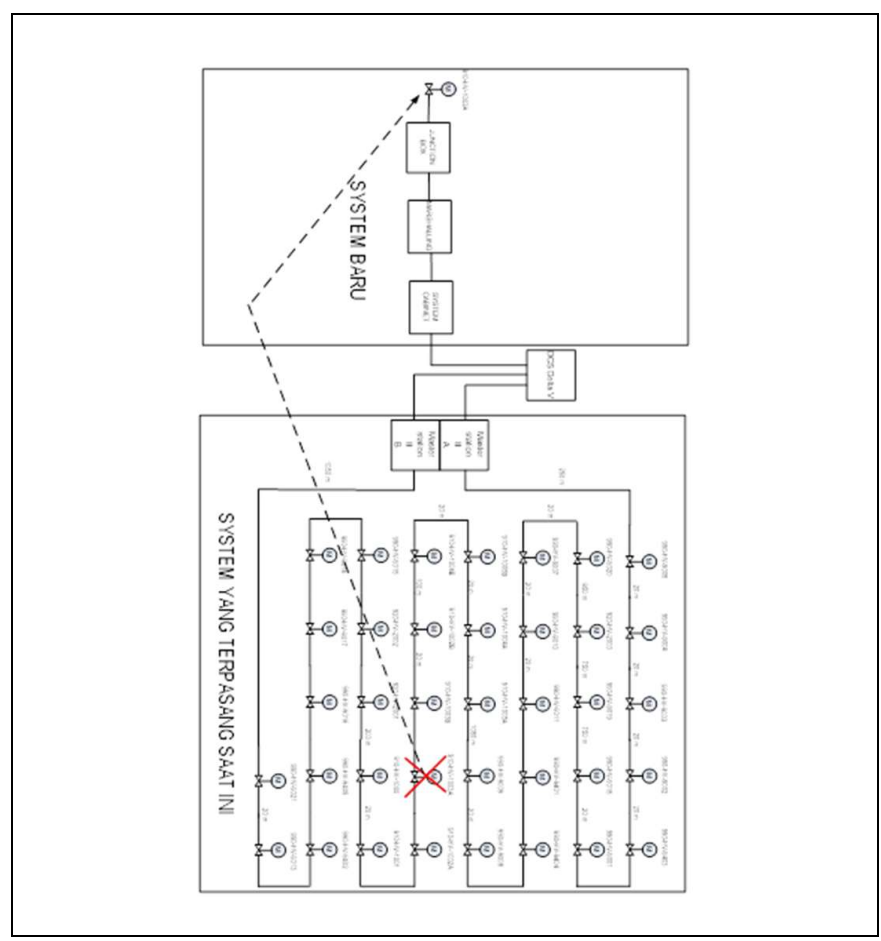

Fig. 8. System Modification 


\section{References}

[1] S. Sukaridhoto, "Komunikasi Data Dan Komputer Dasar Dasar Komunikasi Data," PENS. Surabaya, 2016.

[2] M. B. A. M Mustaghfirin Amin, Instalasi Motor Listrik. ron.

[3] I. M. Parsa, H. Harijono, and H. Sosiawan, "RANCANGAN ALAT BELAH KAYU SISTEM PUTARAN GERGAJI DENGAN PENGATURAN TEKANAN MOTOR LISTRIK," J. Teknol., vol. 14, no. 1, pp. 1-9, 2020.

[4] D. Ferdiansyah, "Perancangan Jaringan Vlan (Virtual Local Area Network) Kementerian Komunikasi dan Informatika RI,” Simnasiptek 2017, vol. 1, no. 1, pp. 1-6, 2017.

[5] R. Arifuddin, D. R. Santoso, and O. Setyawati, "Pengembangan Sistem Akuisisi Data Nirkabel untuk Pengukuran Distribusi Suhu Bawah Permukaan," J. EECCIS, vol. 9, no. 2, pp. 123-129, 2016.

[6] I. ENGINEERS'HANDBOOK, "Process Control and Optimization." CRC press, BG Liptak, Florida, USA, 2006.

[7] B. M. Zacour, J. K. Drennen, and C. A. Anderson, "Hybrid controls combining first-principle calculations with empirical modeling for fully automated fluid bed processing," J. Pharm. Innov., vol. 7, no. 3-4, pp. 140-150, 2012. 